\title{
DESIGN BASIS ACCIDENT ANALYSIS OF A SMALL MODULAR REACTOR
}

\author{
Jivan Khatry ${ }^{1}$, Fatih Aydogan ${ }^{1, *}$
}

\begin{abstract}
The International Reactor Innovative and Secure (IRIS) is an integrated small modular reactor (SMR) designed by Westinghouse Electric Company and a consortium of organizations. It has a thermal electric power rating of 1000 MWth and an electric power rating of 335 MWe. Being an SMR that features a derivative pressurized water reactor design, it contains the core, upper plenum, lower plenum, pressurizer, reactor coolant pumps, and steam generators in a single reactor vessel. An important feature of the IRIS is passive safety systems. Passive safety systems don't require mechanical/electrical inputs for operation and rely on natural laws, material properties, and stored internal energy for hazard mitigation. In this work, a RELAP5 model of IRIS was constructed. A small-break loss-of coolant accident (SBLOCA) is simulated where the six major stages of SBLOCA response: (i) break initiation; (ii) blowdown; (iii) vessel depressurization by condensation and automatic depressurization system (ADS); (iv) pressure equalization; ( $\mathrm{v}$ ) reactor vessel/containment vessel depressurization; and (vi) long-term cooling are demonstrated. This paper demonstrates how efficiently the passive cooling systems work in mitigating the hazard.
\end{abstract}

\section{Keywords: Passive Safety Systems, IRIS, RELAP5, Small Modular Reactor, SBLOCA}

\section{INTRODUCTION}

The International Reactor Innovative and Secure (IRIS) is an integrated small modular reactor (SMR) designed by Westinghouse Electric Company and a consortium of organizations. It has a thermal power rating of $1000 \mathrm{MWth}$ and an electric power rating of $335 \mathrm{MWe}$. It is characterized as an SMR, despite exceeding the DOE's power rating to qualify as an SMR. The DOE defines an SMR as a nuclear reactor that has a power rating of 300 MWe or less.

SMRS are desired because of the following safety and economical benefits [1]. The following safety benefits make SMRs a viable option:

a. Passive decay heat removal by natural circulation,

b. Smaller source term inventory,

c. Elimination of postulated accidents by simplified design,

d. Reduction in Emergency Planning Zone,

e. Below grade construction of the reactor vessel.

The following economic benefits make SMRs a viable option:

f. Flexibility to add reactor units,

g. Decreased financial risk,

h. Potential replacement of old coal plants,

i. Usage of domestic resources, such as forgings and manufacturing,

j. Job creation.

The following design features are generally common for the SMRs:

- Incorporation of primary system components into a single reactor vessel,

- $\quad$ Passive safety systems,

- Smaller core,

- Increased ratio of water inventory to decay heat for more effective decay heat removal,

- Vessel and component layouts that facilitate natural convection cooling of the core and vessel,

- Below-grade construction of the reactor vessel and spent fuel storage pool for enhanced resistance to seismic events and improved security.

- $\quad$ Transportable SMR components from factory to the site. 
As an SMR that is a derivative design of a pressurized water reactor (PWR), IRIS has the lower plenum, core, upper plenum, pressurizer, 8 spool-type reactor coolant pumps, 8 helical-coil steam generators, and the downcomer region in one reactor vessel. The reactor vessel has the dimensions of $6.20 \mathrm{~m}$ (inner diameter) and $23.52 \mathrm{~m}$ (overall height) [2].

The reactor core and fuel design of IRIS utilize 264 fuel rods positioned in a 17 x 17 square array. The central square is for in-core instrumentation while the remaining 24 squares are for guide thimbles. Altogether, there are 89 fuel assembles which form a core with an active fuel height of $4.267 \mathrm{~m}$. Like other light water reactors (LWRS), the fuel is UO2 with an enrichment of $4.95 \%$. The fuel rod diameter is 0.374 [2]. Table 1 summarizes the main parameters of the IRIS design. Figures 1-2 show the diagram of the reactor model and the diagram of the containment.

Table 1. Main parameters of the IRIS design

\begin{tabular}{|c|c|}
\hline Parameters & Quantity/Details \\
\hline Reactor power & $1000 \mathrm{MW}$ th $(335 \mathrm{MWe})$ \\
\hline Reactor core inlet temperature & $292^{\circ} \mathrm{C}$ \\
\hline Reactor core outlet temperature & $330^{\circ} \mathrm{C}$ \\
\hline Reactor coolant circulation & Forced \\
\hline Maximum fuel enrichment & $\sim 5 \%$ \\
\hline Refueling frequency & 3.5 years \\
\hline Control rod drive mechanisms (CRDMs) & External \\
\hline Mode of reactivity control & Control rods, boric acid \\
\hline Reactor coolant operating pressure & $15.513 \mathrm{Mpa}$ \\
\hline Number of reactor coolant pumps & 8 \\
\hline Number of steam generators & 8 \\
\hline Type of safety systems & Passive \\
\hline
\end{tabular}

Table 2. Parameters of IRIS steam generator

\begin{tabular}{|l|l|}
\hline Rated power & $125 \mathrm{MW}$ \\
\hline Tube outside diameter & $17.46 \mathrm{~mm}$ \\
\hline Tube thickness & $2.11 \mathrm{~mm}$ \\
\hline Tube inside diameter & $13.24 \mathrm{~mm}$ \\
\hline External shell inside diameter & $1620 \mathrm{~mm}$ \\
\hline Internal shell outside diameter & $610 \mathrm{~mm}$ \\
\hline Number of helical rows & \\
\hline Tubes number & \\
\hline Tube bundle average length & $32000 \mathrm{~mm}$ \\
\hline SG height (headers centerline) & $7900 \mathrm{~mm}$ \\
\hline SG overall height & $8500 \mathrm{~mm}$ \\
\hline Primary side inlet temperature & $328.4 \mathrm{C}$ \\
\hline Primary side outlet temperature & $292 \mathrm{C}$ \\
\hline Feed-water temperature & $223.9 \mathrm{C}$ \\
\hline Steam temperature & $317 \mathrm{C}$ \\
\hline Primary side pressure & $15.5 \mathrm{MPa}$ \\
\hline Steam outlet pressure & $5.8 \mathrm{MPa}$ \\
\hline Primary flow rate & $589 \mathrm{Kg} / \mathrm{s}$ \\
\hline Secondary flow rate & $62.5 \mathrm{Kg} / \mathrm{s}$ \\
\hline Primary side pressure loss & $72 \mathrm{kPa}$ \\
\hline Secondary side pressure loss & $296 \mathrm{kPa}$ \\
\hline
\end{tabular}

The pressurizer of the IRIS design is on the top part of the reactor vessel. Compared to a normal PWR, there are holes going through the pressurizer in order to accommodate the CRDMs [2]. In addition, this pressurizer has a closed cell insulation to limit the heat transfer between the fluid in the pressurizer and the reactor coolant. 
The bottom of this pressurizer contains heater rods and also has holes to allow water insurge and outsurge to/from pressurizer region. The pressurizer of IRIS has a volume of $71 \mathrm{~m}^{3}$ out of which $49 \mathrm{~m}^{3}$ is occupied by steam.

The reactor coolant pumps of the IRIS design involve a spool-type design, which requires high flow rates and a low developed head [2]. The motor and pump possess two concentric cylinders where the outer ring serves as the stationary stator and the inner ring as rotor. These pumps should eliminate the outcomes of a loss-of-flow accident. They have a low head of $19.1 \mathrm{~m}$ [3].

The steam generators of IRIS are once-through, helical-coil tube bundle design. Here, the primary coolant is circulated via the shell-side and the secondary coolant is circulated via the tube-side. One of the advantages of having a helical-coil tube bundle design is that it can manage thermal expansion in the absence of extreme mechanical stress and due to its strong resistance to vibrations from flow [2]. Table 2 shows the main parameters of a single IRIS steam generator. These are taken from Cinotti et al [4].

The purpose of this report is to present the RELAP5 work done to model IRIS with its passive safety systems.

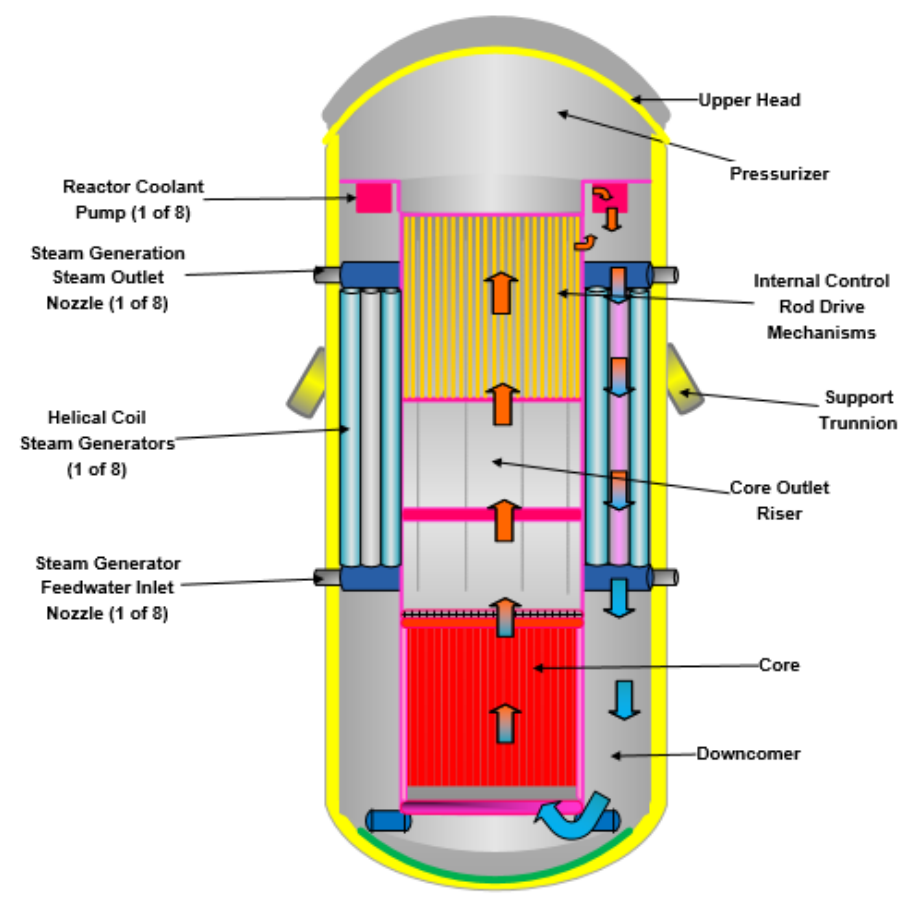

Figure 1. Reactor module of IRIS

\section{PASSIVE SAFETY SYSTEMS OF IRIS}

Figure 3 shows the passive safety systems of IRIS surrounding the reactor vessel. The passive emergency heat removal system (EHRS) of IRIS consists of 4 subsystems. Each of these subsystems possesses a horizontal U-tube heat exchanger (HX) that receives steam from the steam generators and sends condensate back to the steam generator via the main feed-water line. Each heat exchanger is immersed in a refueling water storage tank (RWST). The EHRS provide post-LOCA depressurization and core cooling functions [2].

The emergency boration tanks (EBTs) provide borated water to reactor vessel for an alternative shutdown via direct vessel injection lines. In addition, the EBTs provide limited gravity feed makeup water to primary system $[2]$.

The automatic depressurization system (ADS) works with the EHRS in depressurizing the reactor vessel when coolant inventory is below a particular level. This system has two parallel 4 inch lines with normally closed valves. ADS works to ensure reactor vessel pressures and containment pressures are balanced within a suitable time frame, in order to restrict loss of coolant, and circumvent core uncovery post LOCAs [2].

The pressure suppression system (PSS) consists of 6 water tanks and a common tank for non-condensable gas storage. The suppression water tank is connected to containment atmosphere via vent pipe. The vent pipe is connected to submerged sparger so steam released post LOCA (steam or feed line break accident) is condensed. The PSS restricts maximum containment pressure after the most limiting blowdown event to less than $1 \mathrm{MPa}$ [2]

Due to the absence of extensive piping in the reactor coolant system, the reactor vessel omits the chance of a large break LOCA. Even for a small break LOCA (SBLOCA), the probability and outcomes are reduced due to the significant loss in overall pipe length. The six major stages of SBLOCA response are: (a) break initiation; 


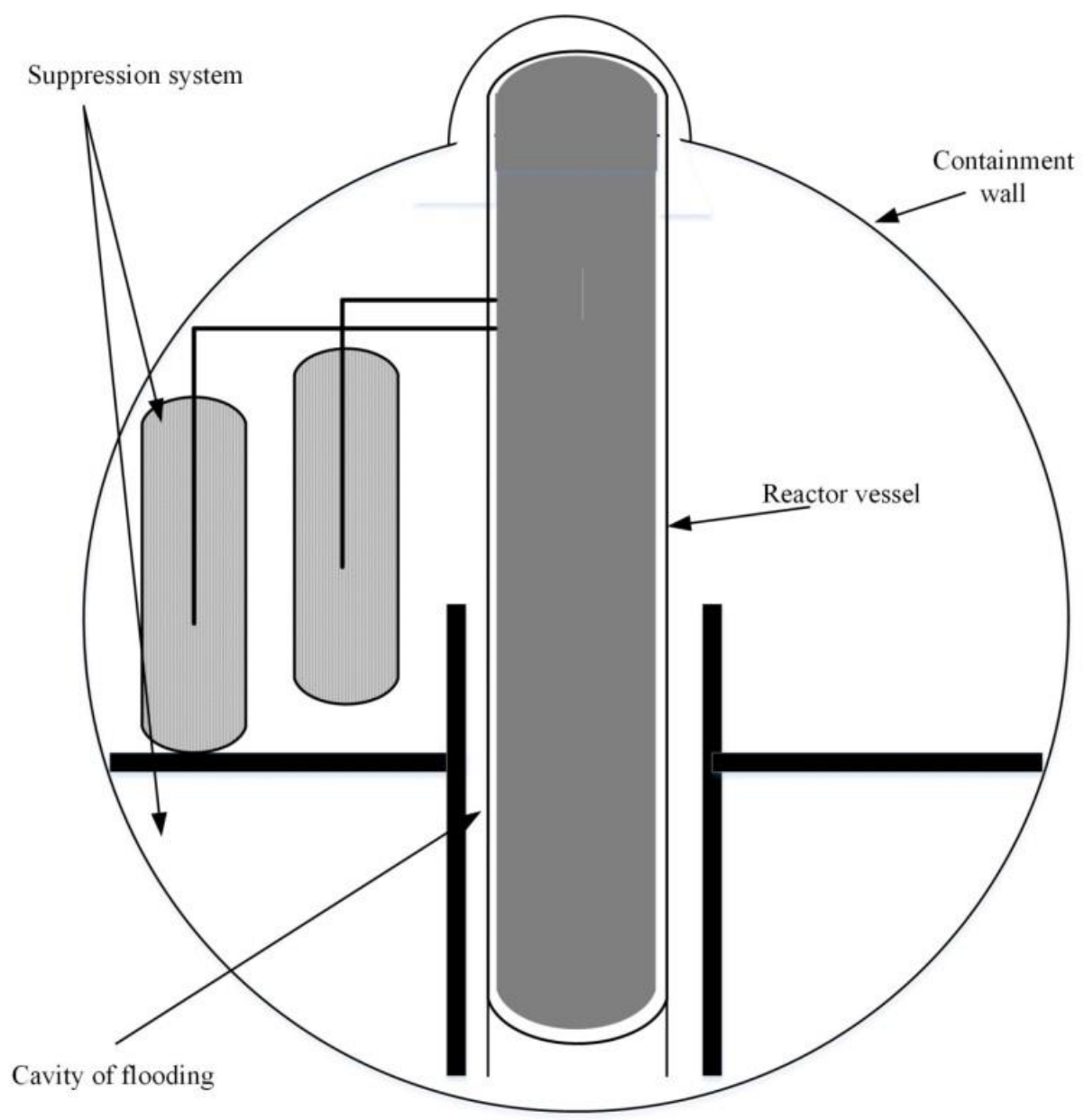

Figure 2. Containment of IRIS

Table 3. Detailed response and time frame associated with SBLOCA

\begin{tabular}{|l|l|}
\hline $\begin{array}{l}\text { Time } \\
\text { (s) }\end{array}$ & Events (with keywords in bold italics) \\
\hline 0 & $\begin{array}{l}\text {-Rupture occurs on the reactor vessel (Break Initiation) } \\
\text {-Reactor vessel pressure declines while the coolant floods containment vessel and pressure in } \\
\text { containment vessel rises (Blowdown Pressure Suppression) }\end{array}$ \\
\hline 12.6 & -Reactor and pump trip \\
\hline 29.5 & -EBTs are activated to provide boration \\
\hline 33.7 & $\begin{array}{l}\text {-Emergency heat removal system (EHRS) starts to function in order to decrease primary system } \\
\text { pressure by condensing steam on the steam generators. This is known as depressurization without loss } \\
\text { of mass }\end{array}$ \\
\hline 51.7 & $\begin{array}{l}\text {-Automatic Depressurization System (ADS) is started in order to support EHRS in reducing the reactor } \\
\text { vessel pressure (Vessel Depressurization by Condensation } \boldsymbol{A} \text { ADS) } \\
\text {-Pressure suppression system reduces containment pressure } \\
\text {-Containment pressure also reduced by lower coolant flow from rupture location. }\end{array}$ \\
\hline 1600 & $\begin{array}{l}\text {-Containment vessel and reactor vessel pressure become equal (Pressure Equalization) } \\
\text { - Containment vessel pressure peak less than } 8 \text { barg } \\
\text {-Break flow stops } \\
\text {-Gravity make-up of borated water from suppression pool becomes available } \\
\text {-Pressure of reactor vessel and containment vessel declines via EHRS (system condenses inside reactor } \\
\text { vessel exceeds decay heat boiloff) (RV/CV Depressurization) } \\
\text {-Break flow reverses since heat is removed directly inside vessel } \\
\text {-Containment vessel pressure decreases post-reactor vessel depressurization as steam from } \\
\text { containment condenses inside pressure vessel }\end{array}$ \\
\hline
\end{tabular}

(b) blowdown pressure suppression; (c) vessel depressurization by condensation \& ADS; (d) pressure equalization; (e) reactor vessel/containment vessel depressurization; and (f) long term cooling. 
Tables $3 \mathrm{a}$ and $3 \mathrm{~b}$ presents the IRIS response systems to a SBLOCA and the approximate start times associated with each event. These are taken from Carelli et al [5], Carelli et al [6], Carelli, Conway, and Oriani [7], and Del Nevo et al [8].

\section{RELAP5 NODALIZATION DIAGRAM OF IRIS}

In Figure 4, a simplified RELAP5 diagram of the IRIS primary system, secondary system and EHRS is presented. This is a simplified adaptation of the nodalization diagram provided by Grgic et al [9]. As far as sizing the components in the RELAP5 model, data from publications available in the public domain were used. In particular, the lengths of the components were taken from Del Nevo et al [8]. Where insufficient information was available, assumptions were made. As is generally the practice in RELAP5, components such as core, pressurizer, steam generator, downcomer, and feed-water/steam lines were modeled as pipes.

As mentioned in the introduction, IRIS has 8 reactor coolant pumps and 8 steam generators. In addition, the EHRS has four HXs that serve as condensers. In RELAP5, the option is to model each of these units or to model a single unit that can do the work of all units. While modeling all units is the most ideal situation, it requires more code. Although modeling all units as a single unit cuts down on the amount of code, it is not useful for situations such as simulating the failure of a single pump or single steam generator. In this work, a single reactor coolant pump to represent all 8 pumps was designed using Aspen Hysys and the particular details (ie. torque, head, power rating) derived by Hysys were used. As for the steam generators, they were modeled as a single counterflow, concentric tube heat exchanger with the primary coolant flowing through the outer annulus and the secondary coolant flowing through the inner tube. Due to the calculated dimensions of this steam generator, the only option left was to model it as a horizontal unit rather than as a vertical unit. In that way, it would avoid the elevation errors in RELAP5.

In addition, the 4 condensers were treated as a single condenser. The same UA value of the steam generator was assumed and its dimensions were calculated. Assumptions concerning the secondary pipe dimensions and the EHRS pipe dimensions were made.

In Figure 5, the $2^{\text {nd }}$ part of the RELAP5 nodalization is presented. This is based on the nodalization diagram presented by Del Nevo et al [8]. Here, the EBT and long-term gravity make-up system is presented. Note that connections to the other parts of the circuit not shown in the image are indicated with component name,

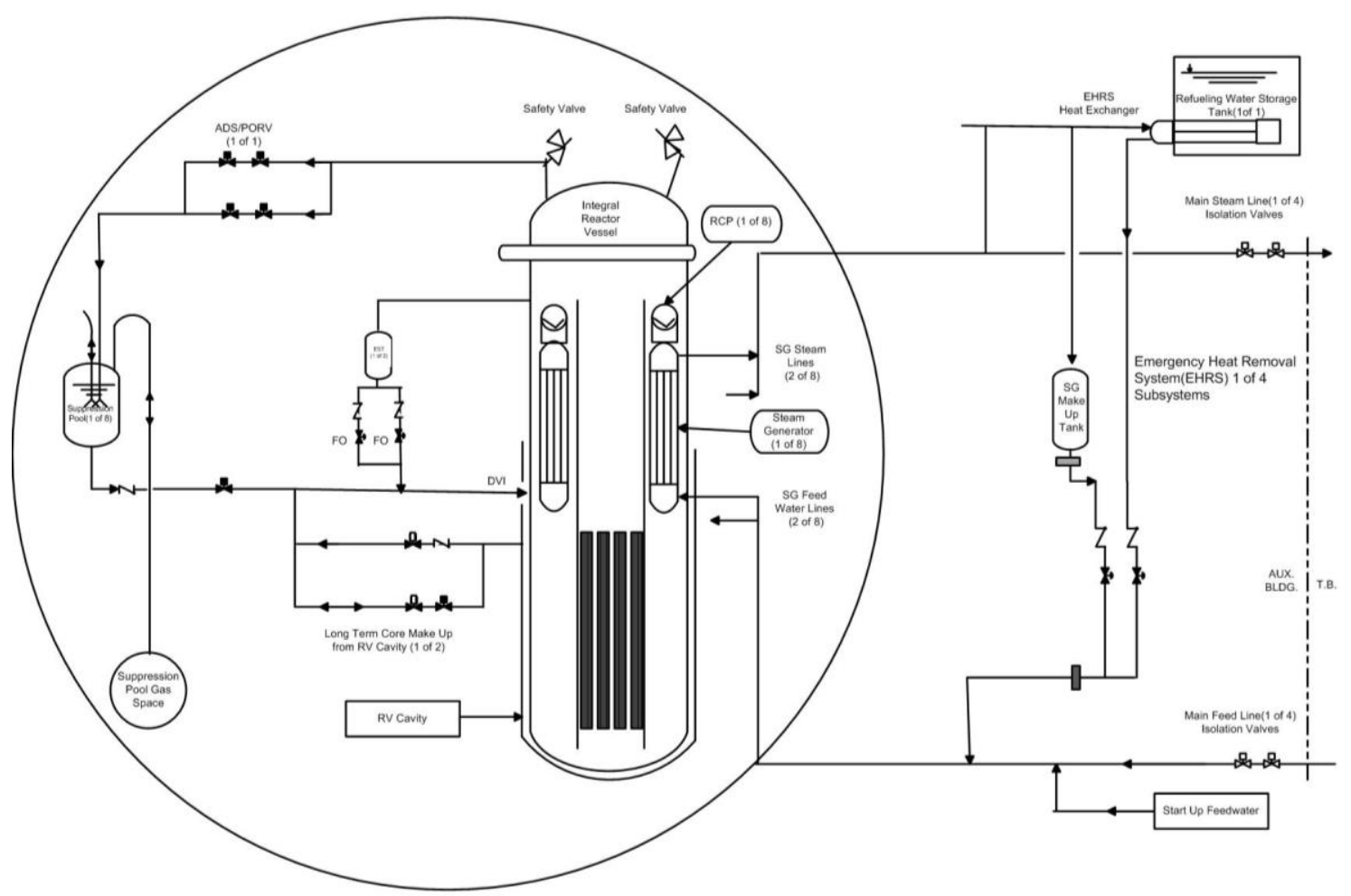

Figure 3. Passive safety systems of IRIS

volume number, and face number in the form CCCVV000F (CCC for component number, VV for volume number, and $\mathrm{F}$ for face number ranging from 1-6) besides each circular node. For example, component 600 has 6 volumes and is oriented vertically heading in the upward direction. The face 1 (bottom face) of the first $1^{\text {st }}$ volume is of component 600 is connected to volume 25, face 2 (top face), of component 101 (represented by 101250002). In 
addition, face 2 of volume 6 of component 600 is connected to face 2, volume 6, and component 240 (represented by 240060002 )

In Figure 6, the $3^{\text {rd }}$ part of the RELAP5 nodalization is presented. This is also based on the nodalization diagram presented by Del Nevo et al [8]. This diagram shows the rest of the components such as the suppression pool tanks, air tank, ADS, vents, drywells, and cavities. Also shown is the SBLOCA valve used to initiate the SBLOCA. This SBLOCA valve is situated between component 150 (volume 2, face 6) and component 810 (volume 24, face 5). Just as in Figure 5, connections to other parts of the circuit not shown are indicated.

\section{RESULTS AND DISCUSSION}

The RELAP5 simulation was carried out such that $500 \mathrm{~s}$ was allotted for the system to reach steady-state. After achieving a steady-state profile, a transient input deck was created where the run is continued from 500s and several events are initiated. This transient input deck was run until a time of 4200 seconds. The area of the rupture was assumed to be $0.0081 \mathrm{~m}^{2}$. Table 4 describes a series of scheduled events.

A decay heat distribution table was entered into the input deck. The decay heat was calculated using the Wigner-Way formula [10]. The Wigner-Way formula is presented as

$$
\left.P_{d}(t)=0.0622 P_{0} \mid t^{-0.2}-\left(t_{0}+t\right)^{-0.2}\right]
$$

The reactor power prior to shutdown was $7.00 \mathrm{E}+8 \mathrm{~W}$. Table 5 presents the decay heat power distribution table utilized for this simulation

In Figure 7-10, we present the graphs from the steady-state run. Figure 7 shows the reactor core inlet and outlet temperatures. Figure 8 presents the temperatures entering and exiting the SG on both the primary and secondary sides. In Figure 9, the pressures entering and exiting the SG are presented. Figure 10 shows the mass flow rates in both the primary and secondary sides.

From Figures 11 and later, we present graphs from the transient runs. In Figure 11, the mass flow rate through the SBLOCA crack is presented. The mass flow rate due to the SBLOCA reaches a maximum of $1289.16 \mathrm{Kg} / \mathrm{s}$. Eventually, it settles down to a mass flow rate of $19.4 \mathrm{Kg} / \mathrm{s}$.

Figure 12 presents the mass flow rates through the $1^{\text {st }}$ and $2^{\text {nd }}$ EBT valve (component\# 605 and component\# 607 in Figure 5, respectively). It is noted how the mass flow rate through the EBT valves fluctuates once they have been operated. The mass flow rate through these valves eventually settles down to $778 \mathrm{~kg} / \mathrm{s}$.

In Figure 13, presented is the mass flow rate through the valves in the IRIS secondary side. Valves that are presented here are component\# 303 and component\# 355 (shown in Figure 4). Note that the closing of these valves are needed to ensure the EHRS is activated. In Figure 13, it is shown that the mass flow rates through these valves become $0 \mathrm{Kg} / \mathrm{s}$ by a time of approximately 535 seconds.

In Figure 14, the mass flow rates through the EHRS valves are shown. These valves are normally closed and are opened when the secondary side valves (component\# 303 and component\# 355) are closed. Eventually, we have a mass flow rate of $149.07 \mathrm{~kg} / \mathrm{s}$ flowing naturally through the EHRS loop. In Figure 15, the mass flow rate through the ADS valve is presented.

Figure 16 shows the EHRS inlet/outlet and water reservoir temperatures. As expected, the temperature of the water in the reservoir is increasing very slowly. The EHRS outlet temperature falls down to the same level as that of the water reservoir. Figure 17 shows the vapor fractions of the entering and exiting fluid. This proves that the EHRS is condensing the incoming steam to water.

Figure 18 shows the reactor core inlet and outlet temperatures declining. Figure 19 shows the pressures entering and exiting the steam generator. Figure 20 shows the inlet and outlet temperatures of the steam generator. As expected, these temperatures are gradually decreasing.

In Figure 21, the pressure in the primary system and the pressure in the drywell are compared. In particular, the pressure in component 150 and volume 2 (used to designate primary side volume) is being compared to that in component 810 and volume 24 (used to designate drywell volume). As expected, the pressure in the drywell increases while the pressure in the primary side falls. This is what is known as the "blowdown phase", described

Table 4. RELAP5 SBLOCA events

\begin{tabular}{|c|c|}
\hline RELAP5 Time (s) & Event \\
\hline 501.0 & SBLOCA initiated (by opening valve 804 in Figure 6 ) \\
\hline 513.6 & Reactor trip initiated \\
\hline 530.5 & Emergency boration tanks provide boration (valves 605 and 607 opened in Figure 5) \\
\hline 534.7 & EHRS initiated (open valves 502 and 510, close valves 303 and 355 in Figure 4) \\
\hline 552.7 & ADS initiated by opening valve 683 (see Figure 6) \\
\hline 4200 & Simulation ends \\
\hline
\end{tabular}


in Table 3a. Also noted is how the pressure in the primary side rises later on and then matches the pressure in the primary side.

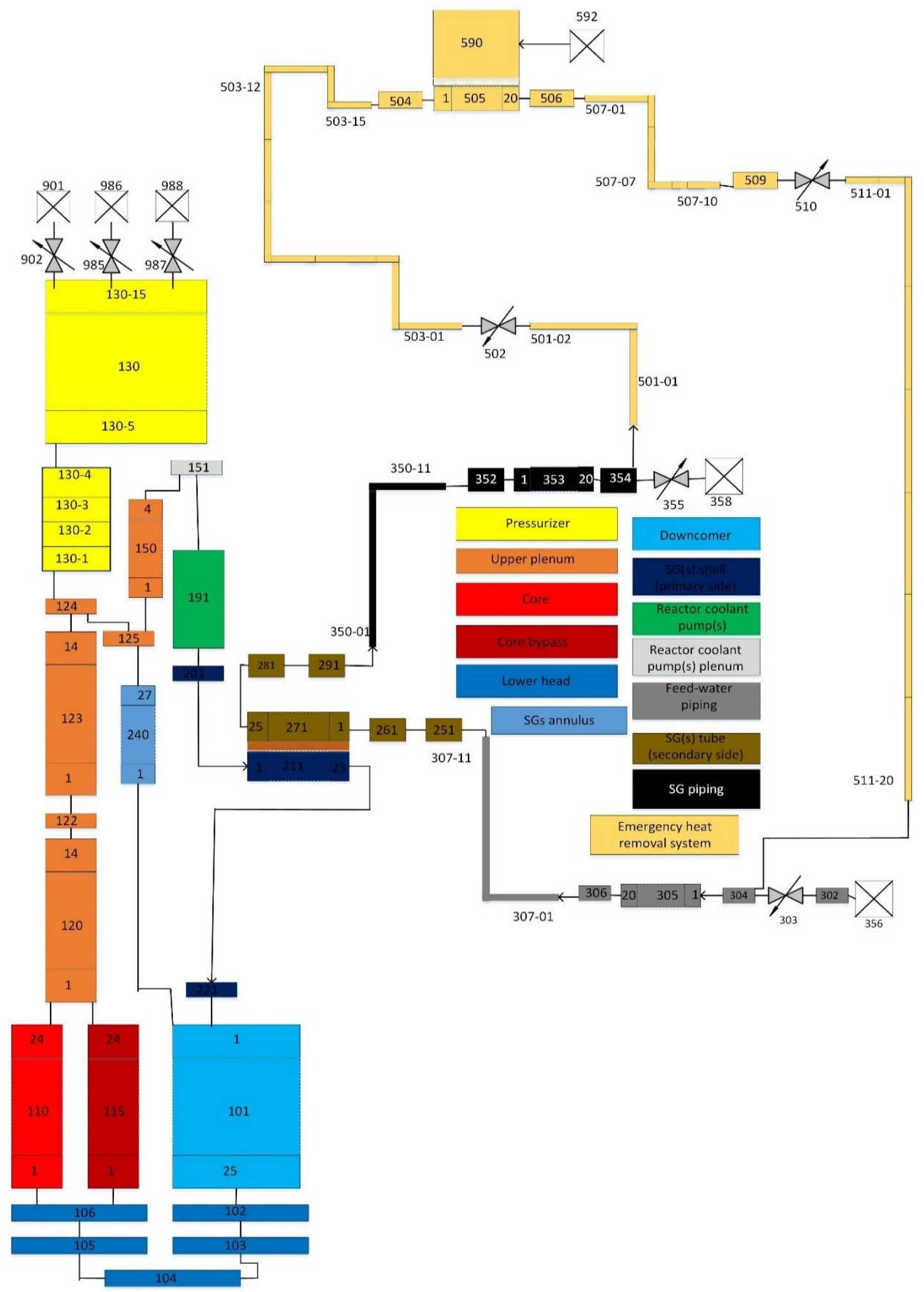

Figure 4. IRIS RELAP5 nodalization diagram part I 
150010002

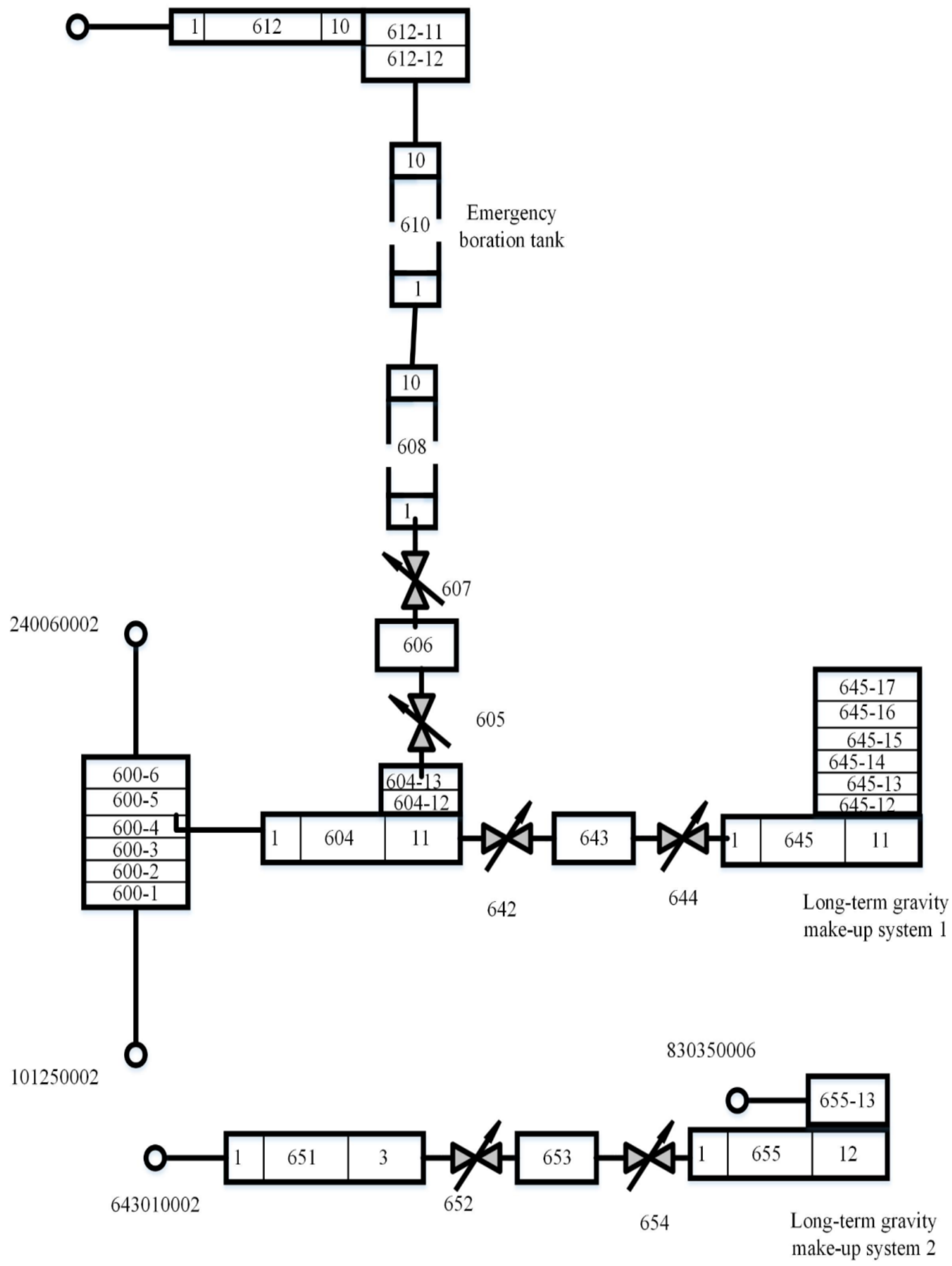

Figure 5. IRIS RELAP5 nodalization diagram part II 


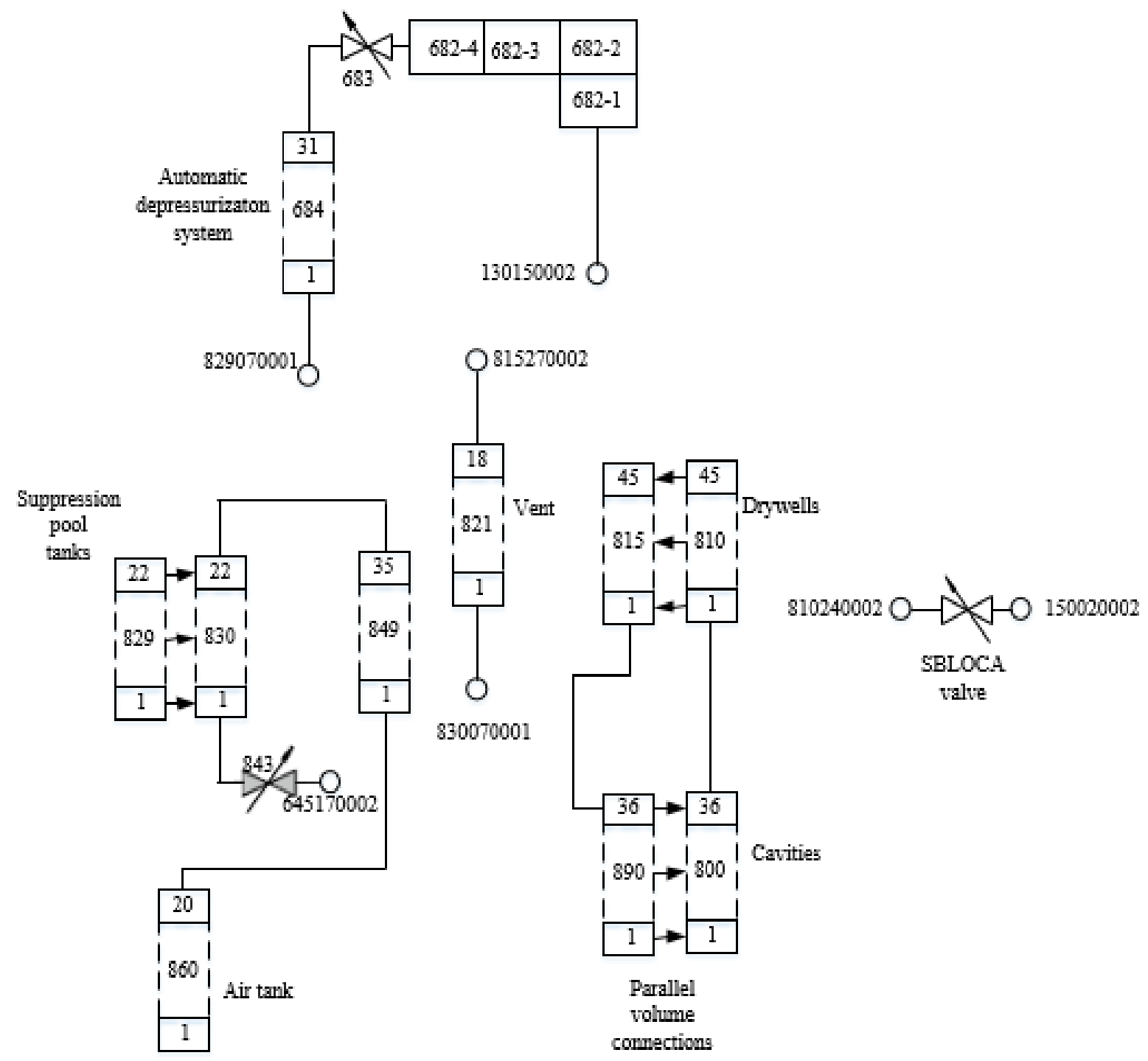

Figure 6. Relap5 nodalization diagram part III

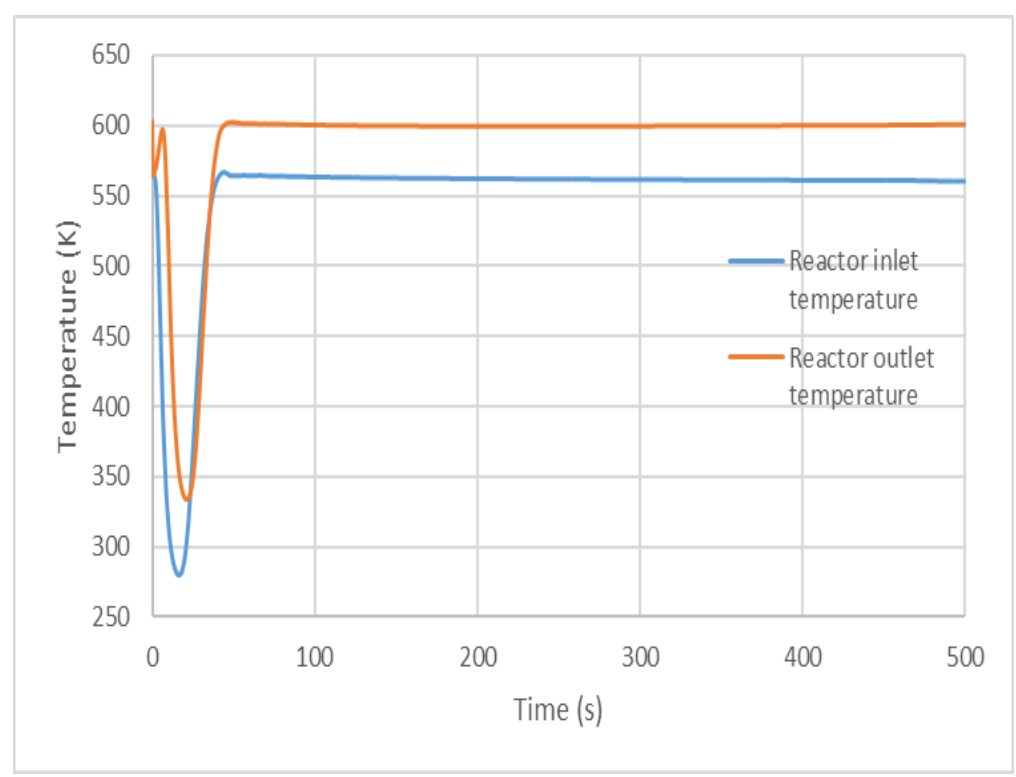

Figure 7. Reactor core inlet/outlet temperatures (steady-state) 
Journal of Thermal Engineering, Research Article, Vol. 3, No. 3, pp. 1241-1258, July, 2017

Table 5. Decay heat distribution

\begin{tabular}{|c|c|}
\hline RELAP5 time(s) & Power $(\mathbf{W})$ \\
\hline 512.7 & $6.76 \mathrm{E}+07$ \\
\hline 513.1 & $4.86 \mathrm{E}+07$ \\
\hline 513.4 & $4.41 \mathrm{E}+07$ \\
\hline 514.6 & $3.65 \mathrm{E}+07$ \\
\hline 516.6 & $3.16 \mathrm{E}+07$ \\
\hline 520.6 & $2.73 \mathrm{E}+07$ \\
\hline 522.6 & $2.61 \mathrm{E}+07$ \\
\hline 542.6 & $2.07 \mathrm{E}+07$ \\
\hline 572.6 & $1.78 \mathrm{E}+07$ \\
\hline 592.6 & $1.67 \mathrm{E}+07$ \\
\hline 662.6 & $1.46 \mathrm{E}+07$ \\
\hline 812.6 & $1.25 \mathrm{E}+07$ \\
\hline 1312.6 & $1.01 \mathrm{E}+07$ \\
\hline 2012.6 & $8.71 \mathrm{E}+06$ \\
\hline 3012.6 & $7.73 \mathrm{E}+06$ \\
\hline 3512.6 & $7.40 \mathrm{E}+06$ \\
\hline 4512.6 & $6.91 \mathrm{E}+06$ \\
\hline
\end{tabular}

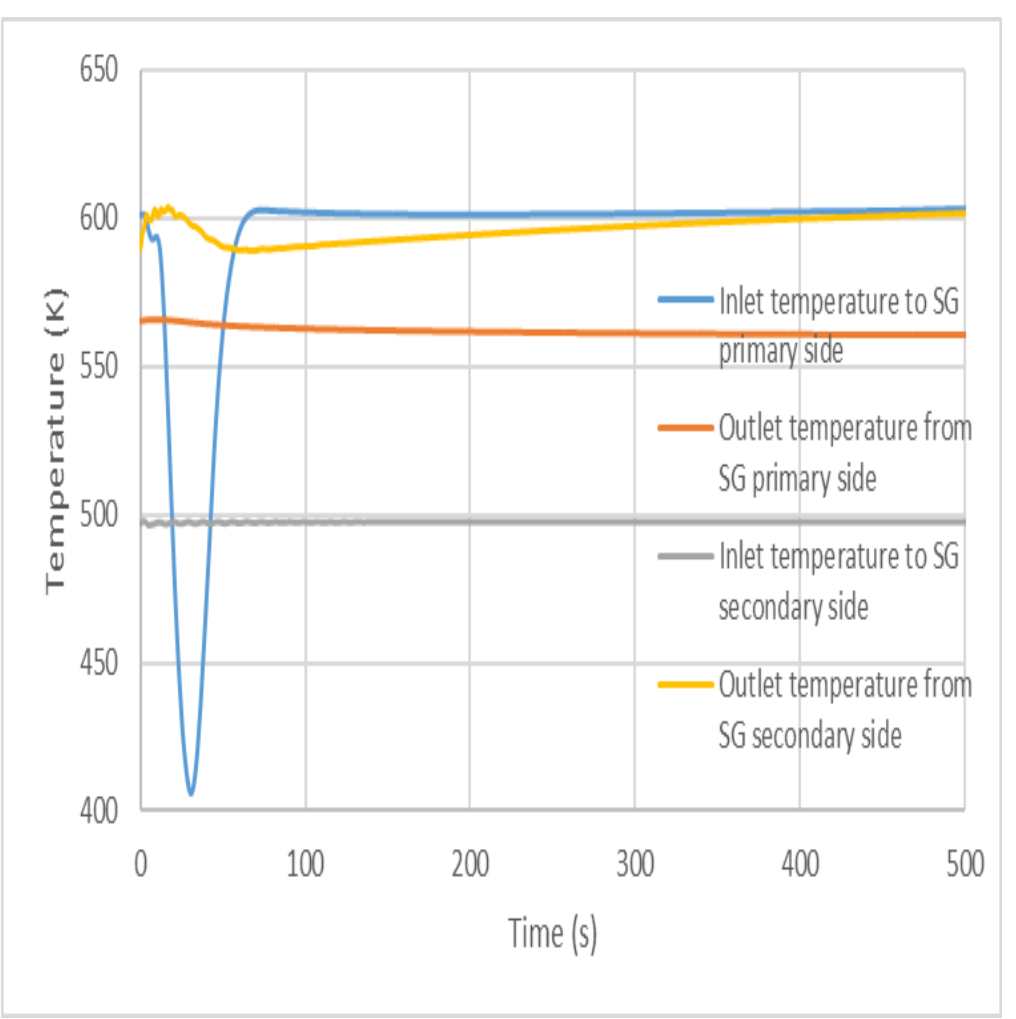

Figure 8. Steam generator inlet/outlet temperatures (steady-state) 
Journal of Thermal Engineering, Research Article, Vol. 3, No. 3, pp. 1241-1258, July, 2017

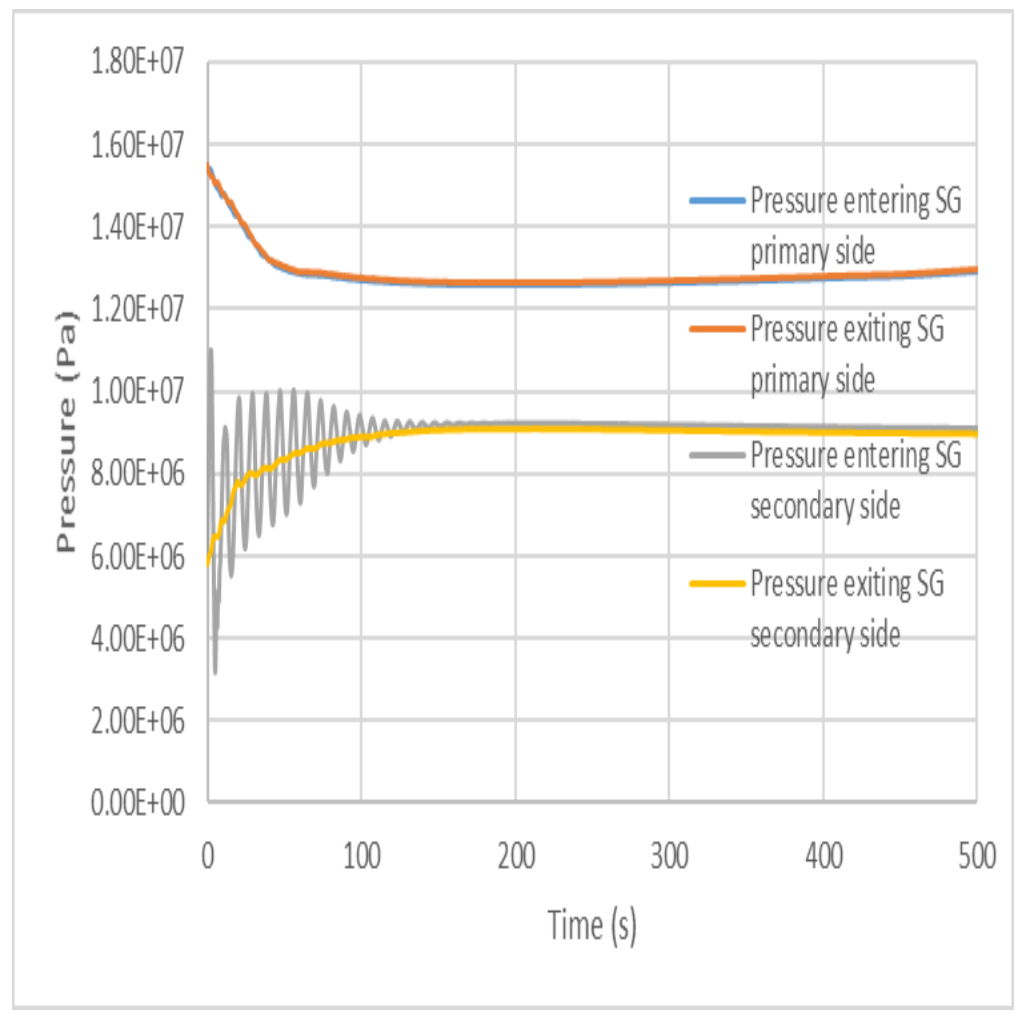

Figure 9. Primary and secondary coolant pressures entering/exiting steam generator (steady-state)

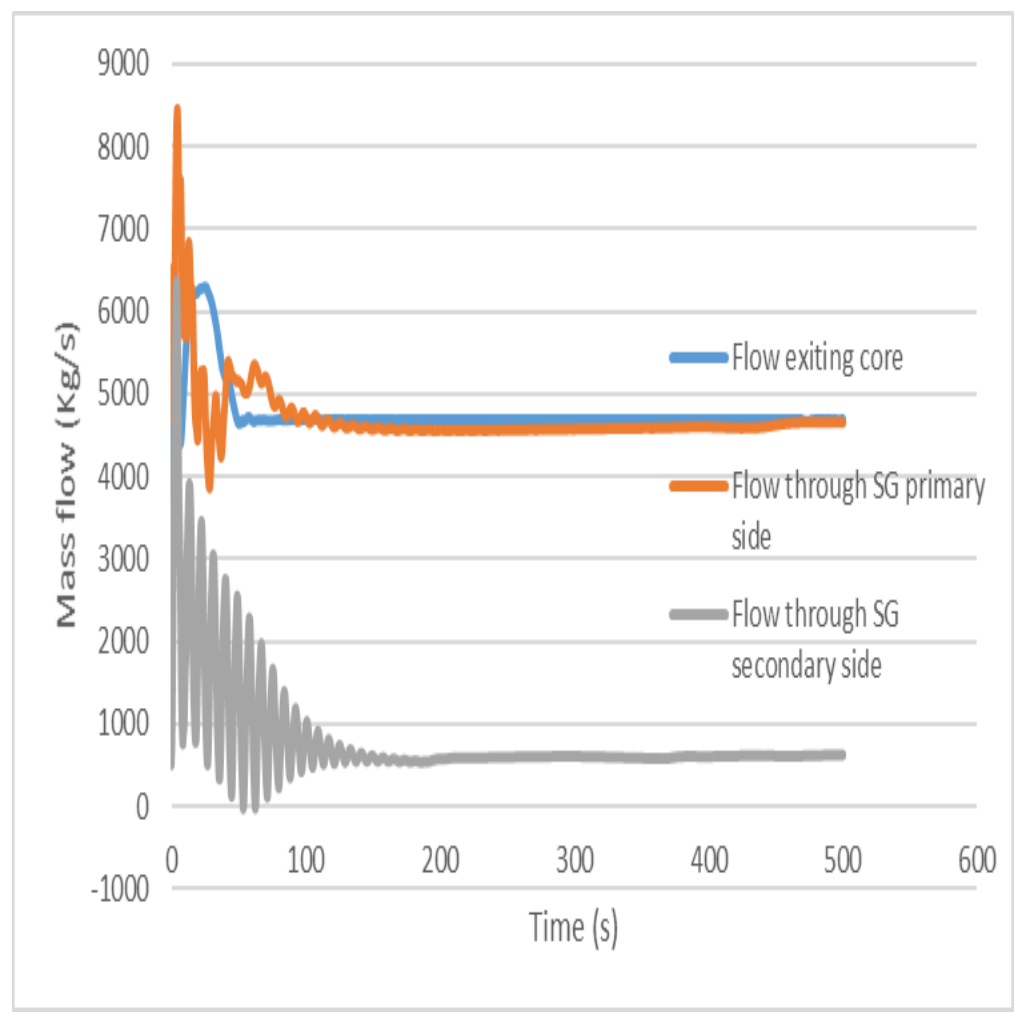

Figure 10. Mass flow rates throughout the system (steady-state) 
Journal of Thermal Engineering, Research Article, Vol. 3, No. 3, pp. 1241-1258, July, 2017

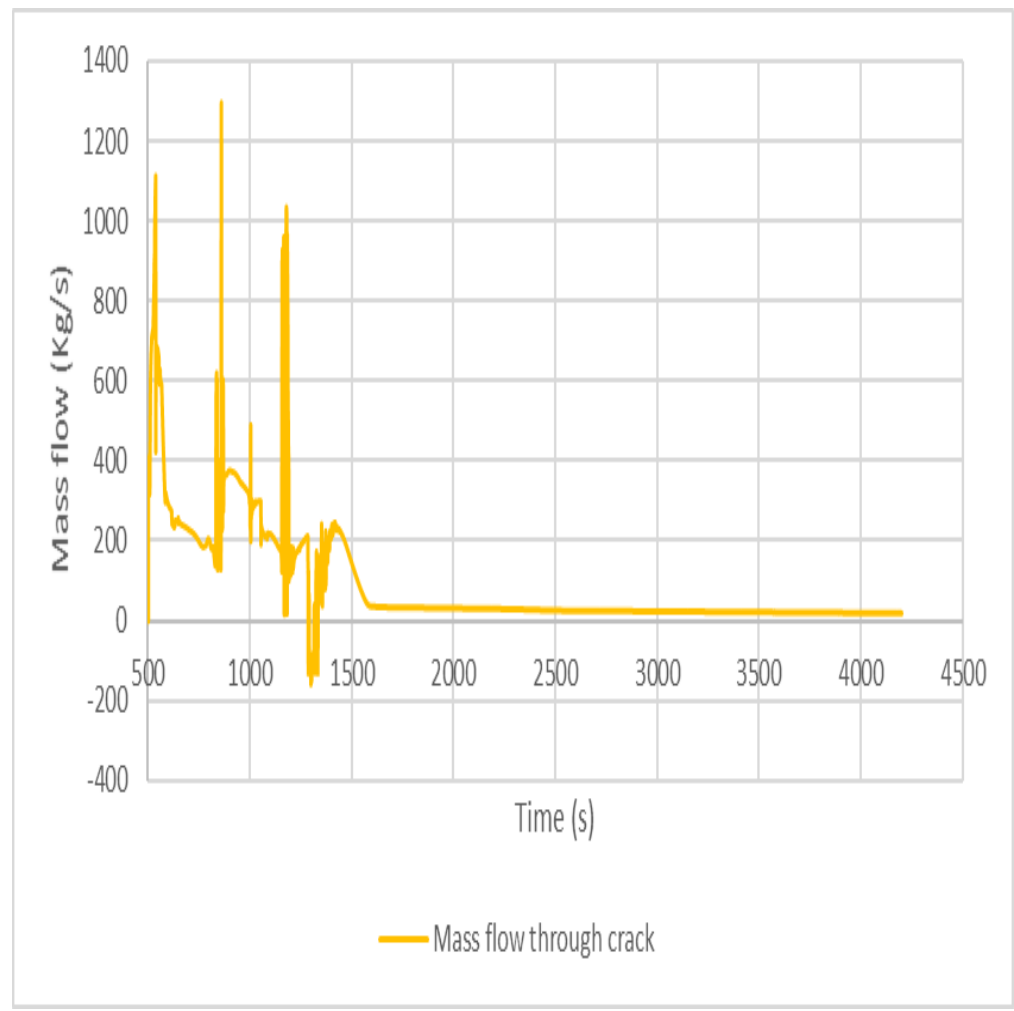

Figure 11. Mass flow rate due to SBLOCA (transient)

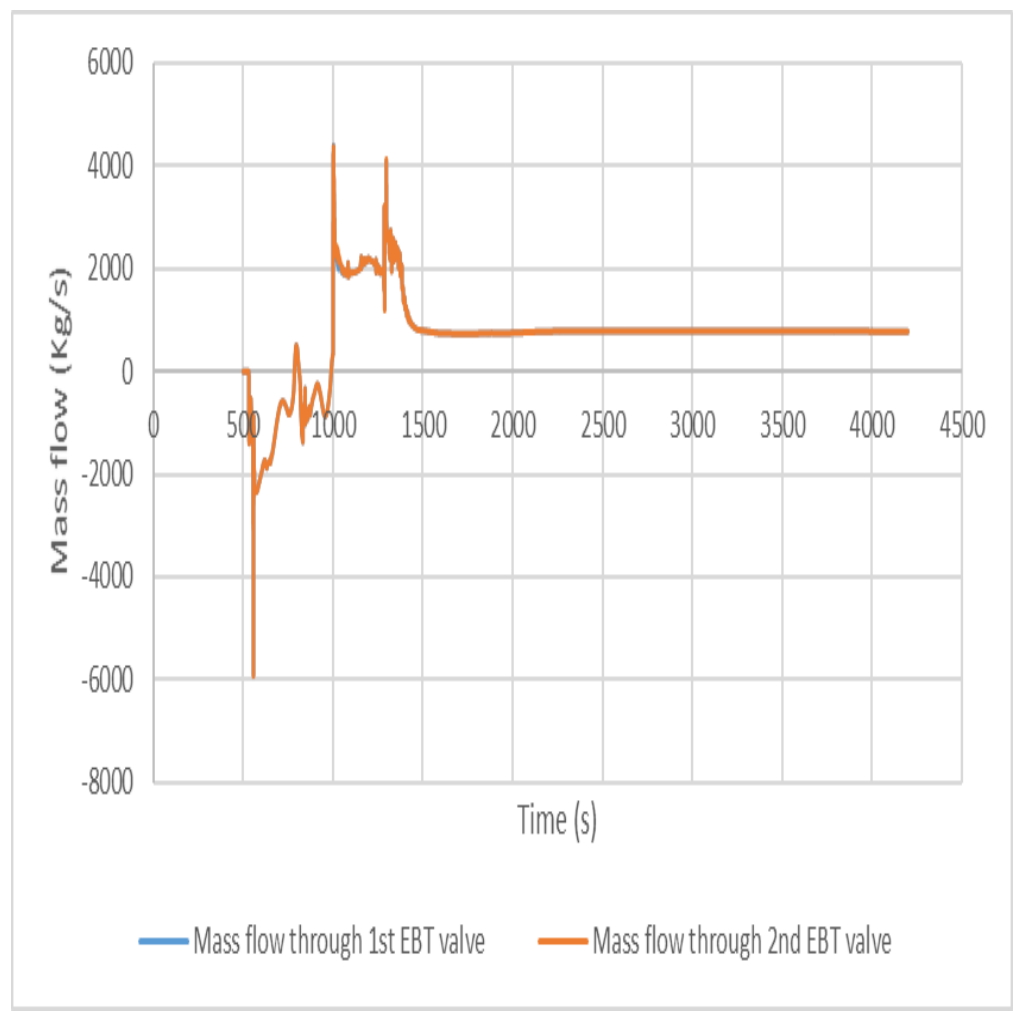

Figure 12. Mass flow rates through EBT valves (transient) 
Journal of Thermal Engineering, Research Article, Vol. 3, No. 3, pp. 1241-1258, July, 2017

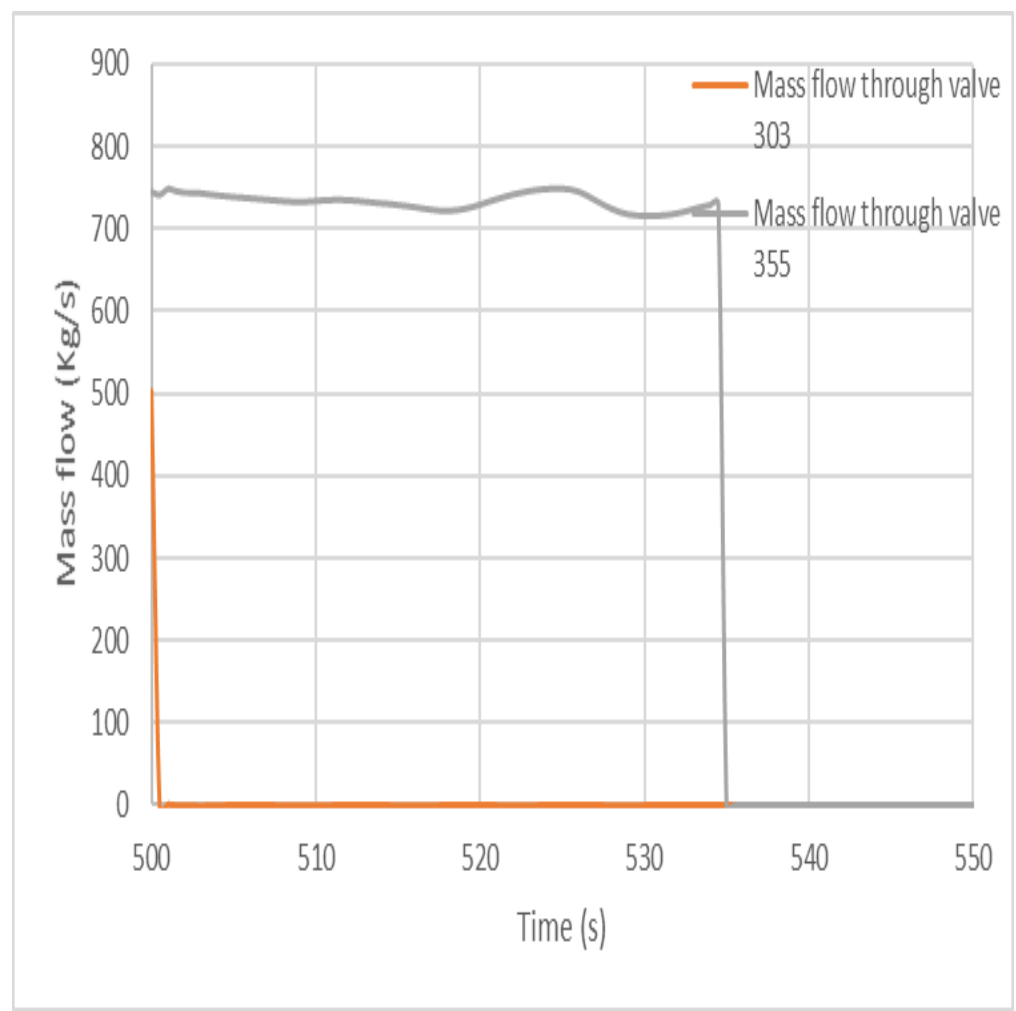

Figure 13. Mass flow rates through secondary side valves (transient)

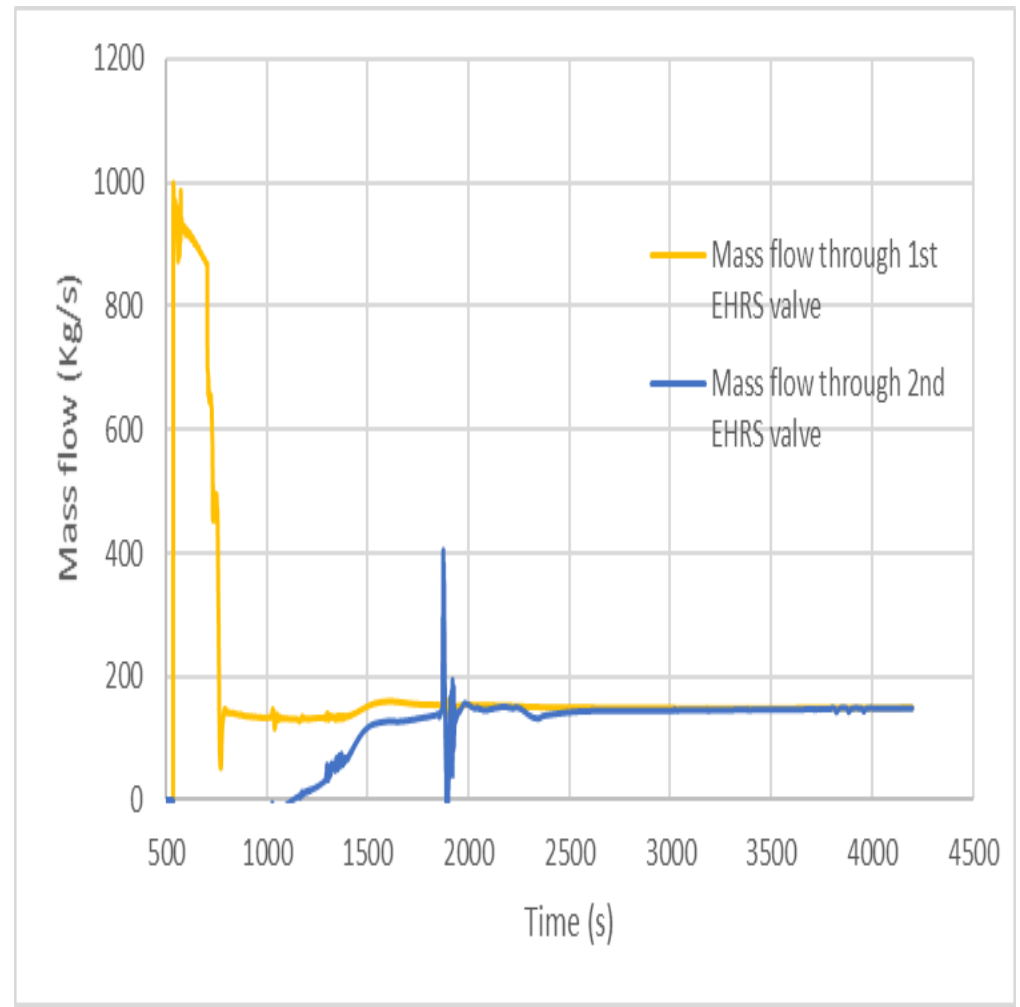

Figure 14. Mass flow through EHRS valve (transient) 
Journal of Thermal Engineering, Research Article, Vol. 3, No. 3, pp. 1241-1258, July, 2017

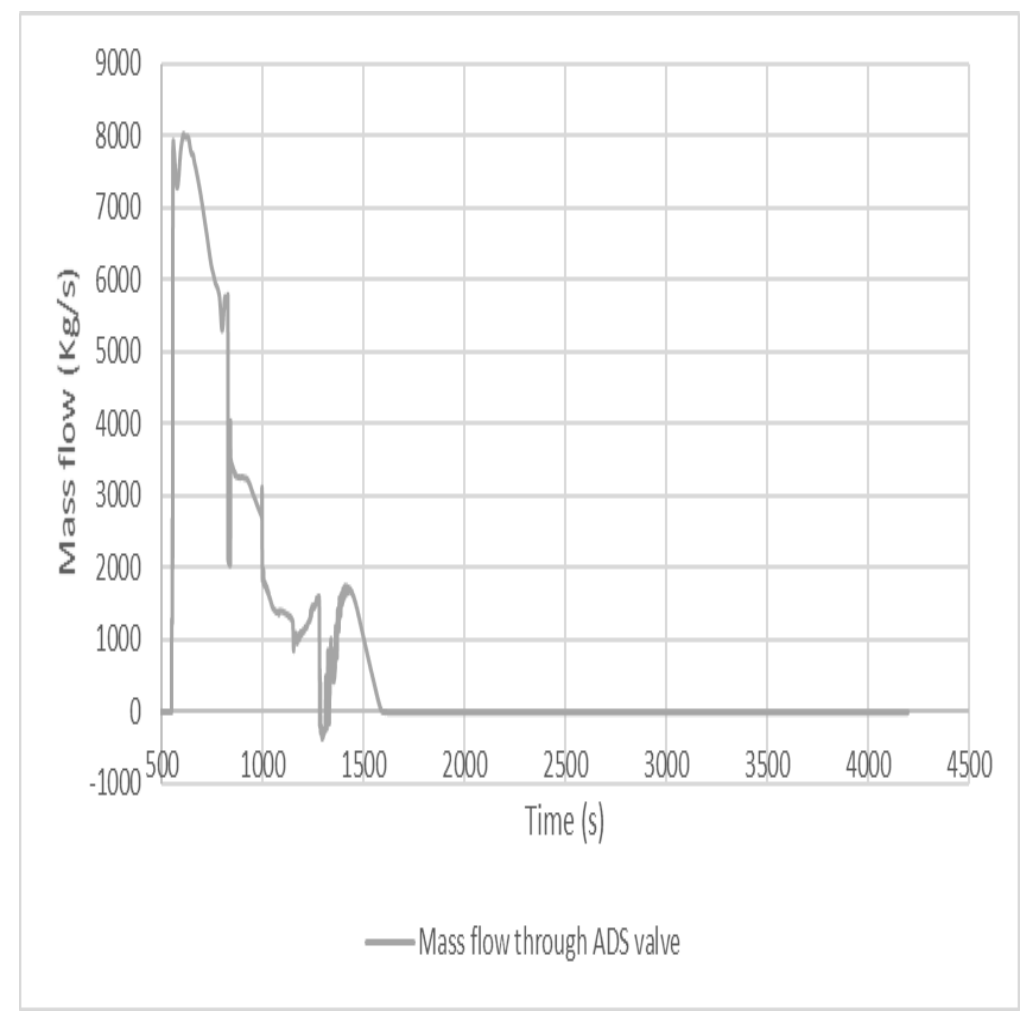

Figure 15. Mass flow rates through ADS valves (transient)

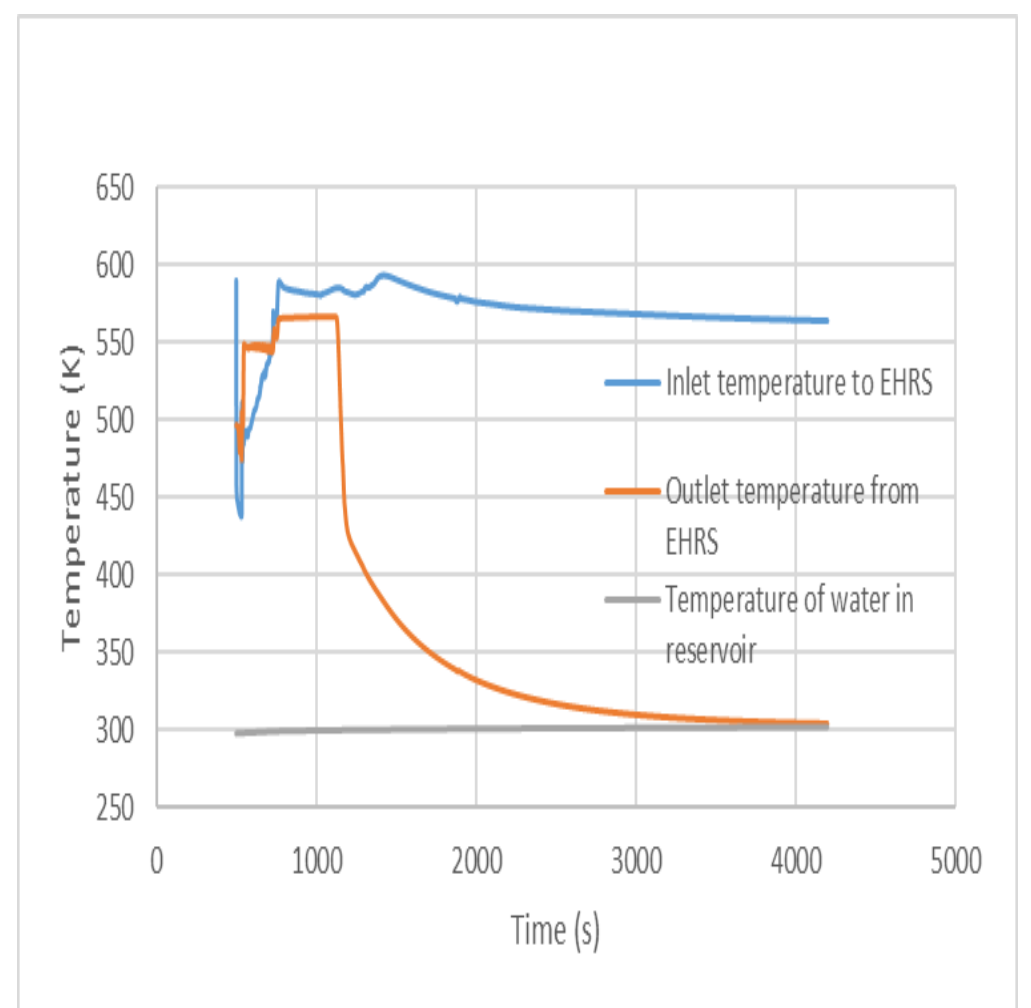

Figure 16. EHRS inlet/outlet and water reservoir temperatures (transient) 
Journal of Thermal Engineering, Research Article, Vol. 3, No. 3, pp. 1241-1258, July, 2017

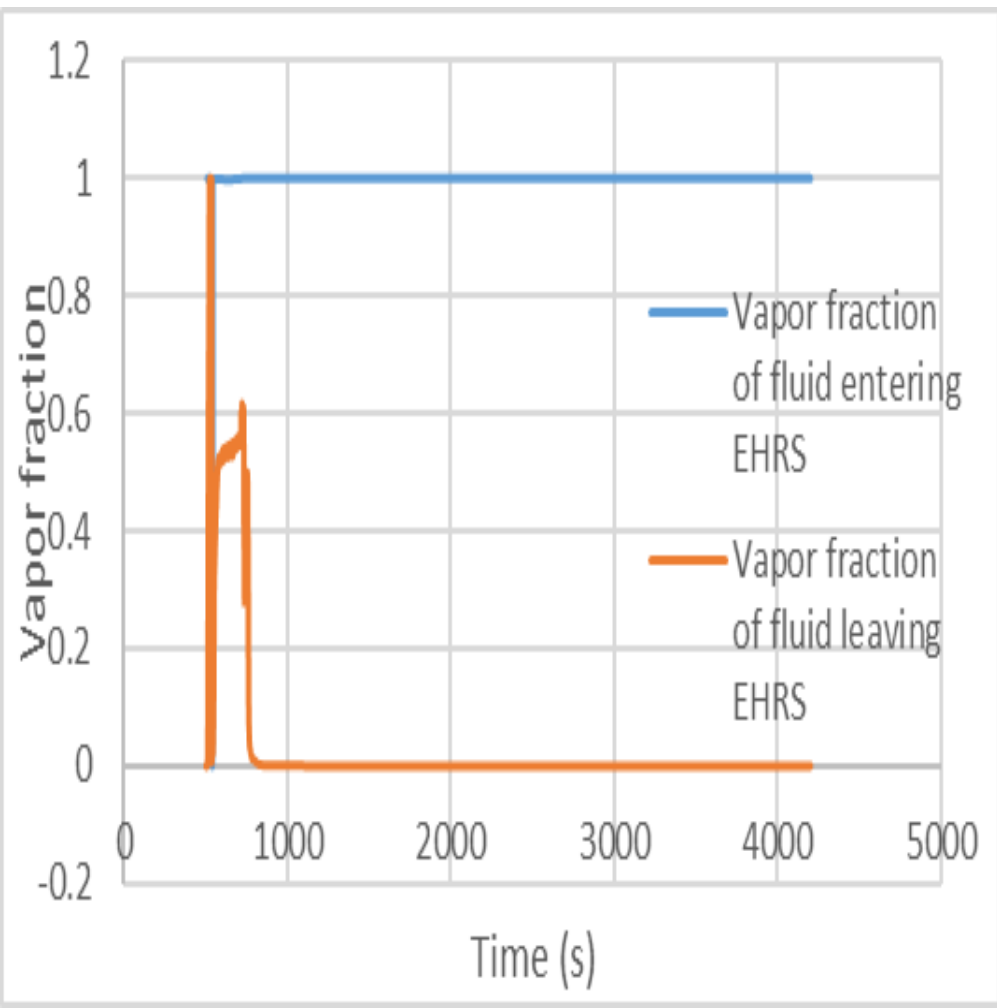

Figure 17. EHRS inlet/outlet vapor fractions (transient)

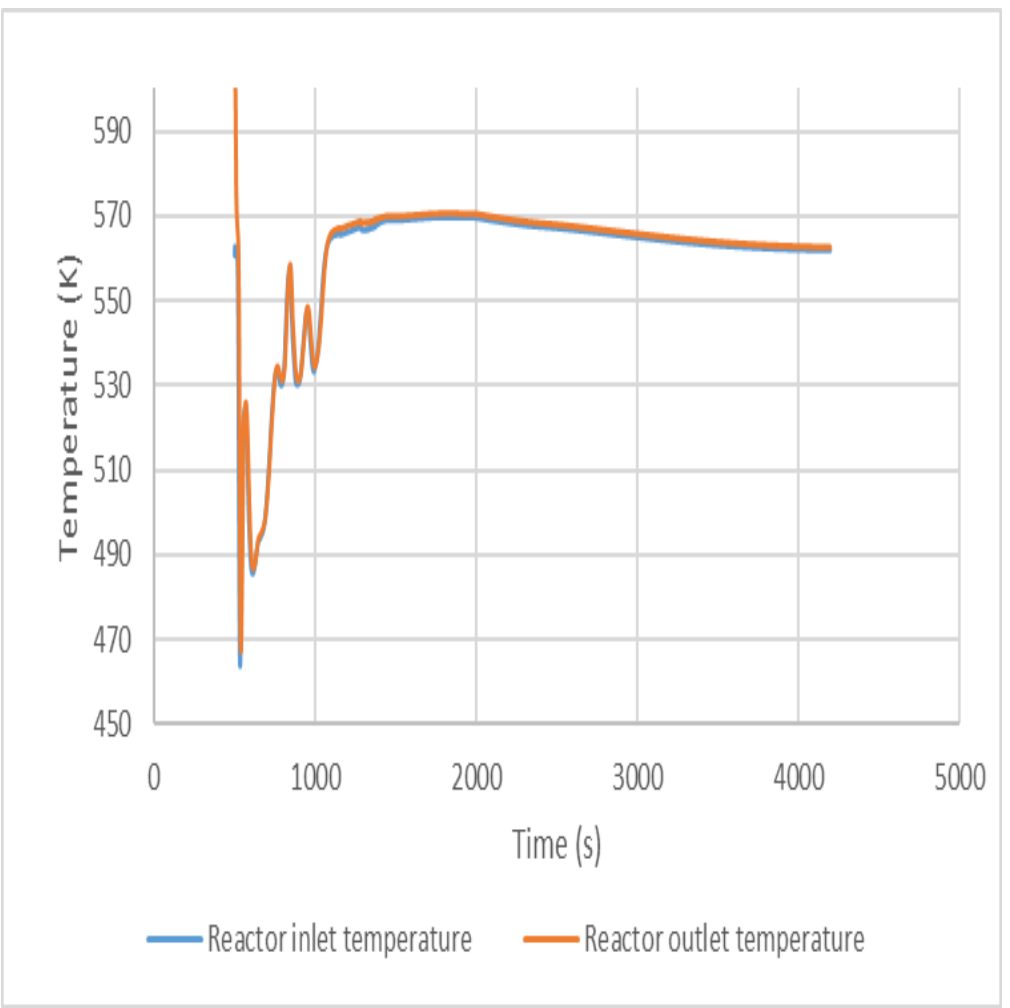

Figure 18. Reactor core inlet/outlet temperatures (transient) 
Journal of Thermal Engineering, Research Article, Vol. 3, No. 3, pp. 1241-1258, July, 2017

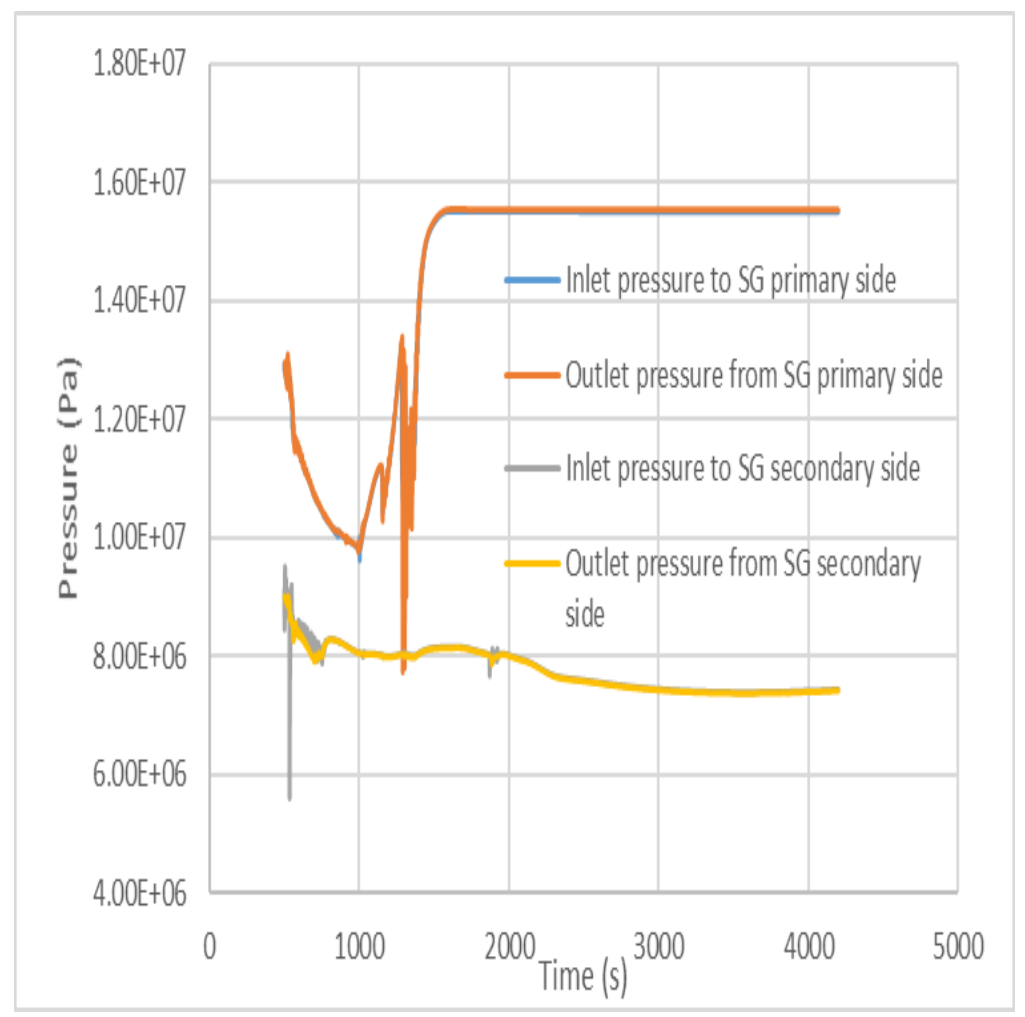

Figure 19. Pressures entering/exiting steam generator (transient)

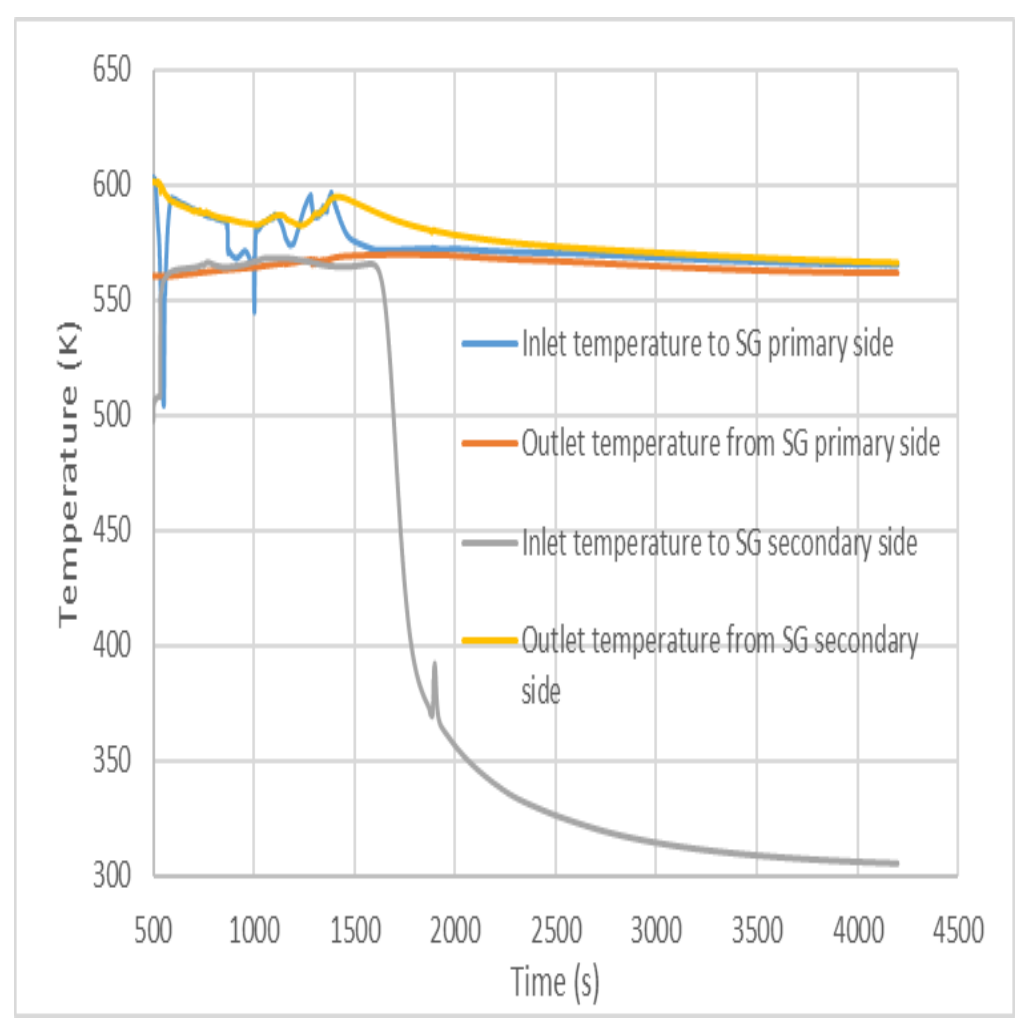

Figure 20. Temperatures entering/exiting steam generator (transient) 


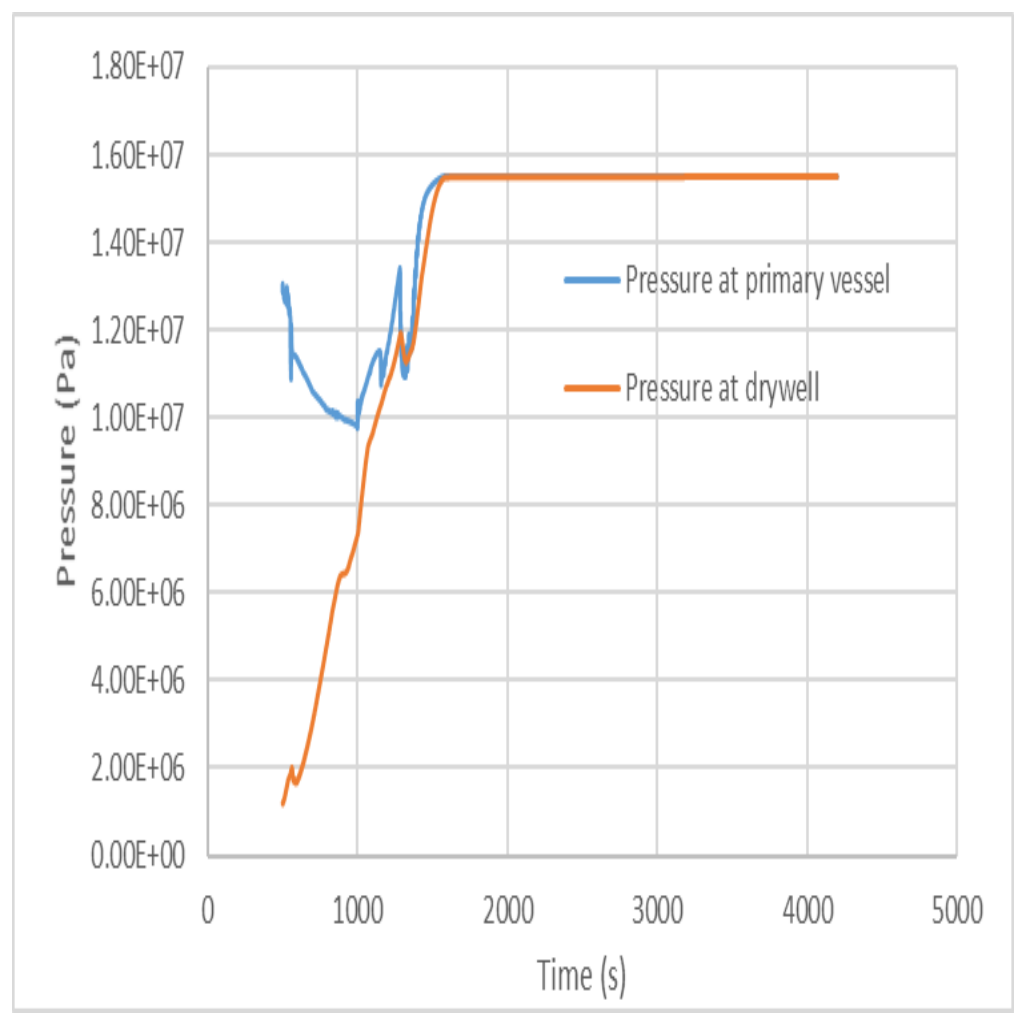

Figure 21. Pressure at primary vessel/drywell (transient)

\section{CONCLUSION}

The SBLOCA on IRIS was modeled using RELAP5 and the simulation lasted for 4200s altogether. The outcome of this simulation demonstrated operation of the passive safety systems, such as the EHRS, EBTs, and ADS. With the EHRS, a natural circulation mass flow rate of $149.07 \mathrm{~kg} / \mathrm{s}$ was achieved. The results showed that the EHRS is indeed condensing the steam that enters it. In addition, the results showed that the pressure in the primary side later rises and becomes equal as that of the drywell. As expected with the temperature distributions, it was expected that they would fall.

Further work could be done to check the mass flow rate through the ADS valve. The results here show that the simulation eventually settles down to a negative flow rate. In addition, the pressures in the primary system and drywell will need to be checked and done again to see if the same behavior is repeated.

\section{ACKNOWLEDGMENTS}

The authors would like to thank the Office of Research and Development of the University of Idaho for supporting this research.

\section{NOMENCLATURE}

$\begin{array}{ll}\mathrm{P}_{d}(\mathrm{t}) & \text { Decay heat } \\ \mathrm{P}_{0} & \text { Reactor power prior to shutdown } \\ \mathrm{t}_{0} & \text { Time of power operation prior to shutdown } \\ \mathrm{t} & \text { post-shutdown time }\end{array}$

$\begin{array}{ll}\text { Abbreviations } & \\ \text { ADS } & \text { Automatic Depressurization System } \\ \text { CRDM } & \text { Control Rod Drive Mechanism } \\ \text { DOE } & \text { Department of Energy } \\ \text { EBTs } & \text { Emergency Boration Tanks } \\ \text { EHRS } & \text { Emergency Heat Removal System } \\ \text { HX } & \text { Heat Exchanger }\end{array}$




$\begin{array}{ll}\text { IRIS } & \text { International Reactor Innovative and Secure } \\ \text { LOCA } & \text { Loss of Coolant Accident } \\ \text { LWR } & \text { Light Water Reactor } \\ \text { PSS } & \text { Pressure Suppression System } \\ \text { PWR } & \text { Pressurized Water Reactor } \\ \text { RELAP } & \text { Reactor Excursion and Leak Analysis Program } \\ \text { RWST } & \text { Refueling Water Storage Tank } \\ \text { SBLOCA } & \text { Small-break loss of coolant accident } \\ \text { SG } & \text { Steam Generator } \\ \text { SMR } & \text { Small Modular Reactor } \\ \text { UO2 } & \text { Uranium Dioxide } \\ \text { US } & \text { United States }\end{array}$

\section{REFERENCES}

[1] Lyons, P., 2012, "Small Modular Reactors - Why are SMR technologies of interest to DOE?", DOE Presentation, 3/16/2012.

[2] Carelli, M. D. et al., 2003, Integral Layout of the IRIS Reactor. Proceedings of ICAPP'03, Cordoba, Spain, May 2003.

[3] Bajs, T., Grgic, D., Segon, V.,2003, Development of RELAP5 Nodalization for IRIS Non-LOCA Transient Analyses. Nuclear Mathematical and Computational Sciences: A Century in Review, A Century Anew, Gatlinburg, Tennessee, April 2003.

[4] Cinotti, L. et al., 2002, Steam Generator of the International Reactor Innovative and Secure. Proceedings of ICONE10, Arlington, VA, April 2002.

[5] Carelli, M. D. et al., 2003, The Design and Safety Features of the IRIS Reactor. $11^{\text {th }}$ International Conference on Nuclear Engineering, Tokyo, Japan, April 20-23, 2003.

[6] Carelli, M. D. et al., 2004, The Design and Safety Features of the IRIS Reactor. Nuclear Engineering and Design, 230, 151-167.

[7] Carelli, M., Conway, L., Oriani, L., 2003, Safety Features of the IRIS Reactor. Nuclear Mathematical and Computational Sciences: A Century in Review, A Century Anew, Gatlinburg, Tennessee, April 6-11, 2003.

[8] Del Nevo, A., Manfredini, A., Oriolo, F., Paci, S.,2004, Integrated Analysis for a Small Break LOCA in the IRIS Reactor using MELCOR and RELAP5 Codes. $5^{\text {th }}$ International Conference on Nuclear Option in Countries with Small and Medium Electricity Grids, Dubrovnik, Croatia, May 16-20, 2004.

[9] Grgic, D. et al., 2004, Coupled RELAP5/GOTHIC Model for IRIS SBLOCA Analysis. $5^{\text {th }}$ International Conference on Nuclear Option in Countries with Small and Medium Electricity Grids, Dubrovnik, Croatia, May 2004

[10] E.E. Lewis. Nuclear Power Reactor Safety, John Wiley \& Sons In, New York. 1977. 